\title{
Diastolic function changes in hypertensive patients and septal bulge
}

\section{- Vlatka Rešković Lukšić*, \\ -Marijan Pašalić, (1) Jadranka Šeparović Hanževački}

University of Zagreb School of Medicine, University Hospital Centre Zagreb, Zagreb, Croatia
RECEIVED:

February 28, 2019

ACCEPTED:

March 24, 2019

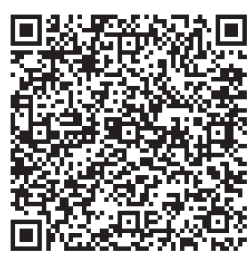

KEYWORDS: arterial hypertension, diastolic function, echocardiography. CITATION: Cardiol Croat. 2019;14(3-4):97. | https://doi.org/10.15836/ccar2019.97

*ADDRESS FOR CORRESPONDENCE: Vlatka Rešković Lukšić, Klinički bolnički centar Zagreb, Kišpatićeva 12, HR10000 Zagreb, Croatia. / Phone: +385-1-2367-491 / E-mail: vlatka.reskovic@gmail.com

ORCID:Vlatka Rešković Lukšić, http://orcid.org/0000-0002-4721-3236 • Marijan Pašalić, http://orcid.org/0000-0002-3197-2190 Jadranka Šeparović Hanževački, http://orcid.org/0000-0002-3437-6407

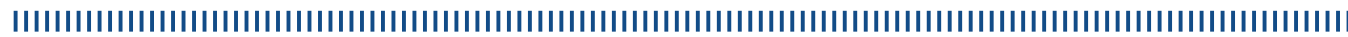

Background: Hypertensive patients with basal septal hypertrophy (BSH) are known to have high filling pressures comparing to healthy controls, eventually leading to diastolic heart failure and poor outcomes..$^{1-3}$ Aim: To investigate if occurrence of basal septal hypertrophy is related to diastolic disfunction in younger patients with uncomplicated arterial hypertension (AH) and no comorbidities compared to hypertensive patients with no BSH.

Patients and Methods: A total of 138 patients aged 18-65 years (mean $48.51 \pm 11.69$ years), 47.8\% men were enrolled. Complete 2D transthoracic echocardiography according to standardized protocol was performed, as well as deformation study using 2D speckle tracking echocardiography. All patients included in the study had a preserved left ventricular ejection fraction (mean 61.35 $\pm 5.07 \%$ ). Basal septal hypertrophy was defined as basal/mid septal thickness ratio $>1.3$, or thickness of the basal interventricular (iv) septum >2mm compared to mid iv septum, along with visual BSH notification.

Results. There were altogether 74 patients (53.6\%) with BSH. Patients in this group were older (51.41 \pm 9.37 vs $45.16 \pm 13.19$ years, $p=0.006)$, with longer duration of $\mathrm{AH}(9.01 \pm 9.67$ vs $5.95 \pm 8.51$ years, $\mathrm{p}=0.009)$. Echocardiographic measurements revealed normal left ventricular (LV) geometry and left atrial (LA) volumes, as well as normal values of standard indices of diastolic function in the whole population. However, patients with BSH showed incipient concentric LV remodeling and relaxation impairment (RWT 0.38 \pm 0.11 vs $0.3 \pm 0.08$, $p<0.001 ;$ LVMI 109.15 \pm 25.33 vs $89.19 \pm 24.59 \mathrm{~g} / \mathrm{m}^{2}, \mathrm{p}<0.001 ; \mathrm{E} / \mathrm{A} 0.96 \pm 0.28$ vs $1.16 \pm 0.39, \mathrm{p}=0.001$; LAVI $32.68 \pm 9.98$ vs $30.02 \pm 11.37, p=0.05$ ). There were no differences among groups according to global deformation measurements. Longitudinal strain was more impaired in three basal LV segments (basal iv septum $-11.38 \pm 4.37 \%$ vs $-14.69 \pm 2.54 \%, p<0.001$; mid iv septum $-16.44 \pm 3.54$ vs $-18,16 \pm 2.9 \%, p=0.01$; basal anteroseptum $-13.38 \pm 4.19$ vs $-15.24 \pm 3.23 \%, p=0.01)$, correlating with indices of diastolic function shown in Table 1 .

Conclusion. BSH is shown to be an early sign of LV relaxation impairment, along with incipient geometry and regional longitudinal deformation changes even in younger patients and in early stages of AH.

TABLE 1. Correlations between regional longitudinal strain and parameters of diastolic function.

\begin{tabular}{llll} 
& E/A & E' sept & E/E'sept \\
\hline LSBAS & $r=-0.249, p=0.011$ & $r=-0.363$, & $r=0.228$, \\
& & $p=0.001$ & $p=0.021$ \\
\hline LSBS & $r=-0.329, p=0.001$ & $r=-0.387$, & $r=0.26$, \\
& & $p=0.001$ & $p=0.007$ \\
\hline \multirow{2}{*}{ LSMS } & $r=-0.211, p=0.029$ & $r=-0311$, & $r=0.224$, \\
& & $p=0.001$ & $P=0.022$ \\
\hline
\end{tabular}

LSBAS=basal anteroseptum longitudinal strain, LSBS= basal septum longitudinal strain, LSMS=mid septum longitudinal strain

LITERATURE IIIIIIIIIIIIIIIIIIIIIIIIIIIIIIIIIIIIIIIIIIIIIIIIIIIIIIIIIIIIIIIIIIIIIIIIIIIIIIIIIIIIIIIIIIIIIIIIIIIII

1. Narayanan A, Aurigemma GP, Chinali M, Hill JC, Meyer TE, Tighe DA. Cardiac mechanics in mild hypertensive heart disease: a speckle-strain imaging study. Circ Cardiovasc Imaging. 2009 Sep;2(5):382-90. https://doi.org/10.1161/CIRCIMAGING.108.811620

2. Galderisi M, Lomoriello VS, Santoro A, Esposito R, Olibet M, Raia R, et al. Differences of myocardial systolic deformation and correlates of diastolic function in competitive rowers and young hypertensives: a speckle-tracking echocardiography study. J Am Soc Echocardiogr. 2010 Nov;23(11):1190-8. https://doi.org/10.1016/j.echo.2010.07.010

3. Mizuguchi Y, Oishi Y, Miyoshi H, luchi A, Nagase N, Oki T. The functional role of longitudinal, circumferential, and radial myocardial deformation for regulating the early impairment of left ventricular contraction and relaxation in patients with cardiovascular risk factors: a study with twodimensional strain imaging. J Am Soc Echocardiogr. 2008 0ct;21(10):1138-44. https://doi.org/10.1016/j.echo.2008.07.016 